\title{
Pengetahuan dan Sikap Ibu dalam Pemberian Jajanan Sehat pada Anak di Taman Kanak -Kanak Baiturrahim Jambi
}

\author{
Iin Indrawati ${ }^{1}$, Faridah ${ }^{2}$ \\ ${ }^{1,2}$ Program Studi D III Keperawatan, STIKes Baiturrahim Jambi \\ Email: iinian737497@gmail.com
}

Submitted : 11/12/2020

Accepted: 06/01/2021

Published: 06/03/2021

\begin{abstract}
Abstrack
Children's food consumption is usually influenced by how conditions are in their household, mothers have an important role in teaching, selecting and even modeling the food and snacks they consume. The research objective was to find out how the influence of health education with emotional demonstration techniques on the knowledge and attitudes of mothers in providing healthy snacks to children at Baiturrahim Kindergarten Jambi.This research is a quantitative study with a quasi-experimental design. The population of this study was 23 mothers whose children attended TK Baiturrahim and the sample technique chosen was total sampling.Maternal knowledge before the intervention was good 16 people (68.7\%), poor 7 people $(31.3 \%)$ and after the intervention was good 21 people (91.3\%), less good 2 people (8.7\%)). As for the attitude variable, it was found that 19 people were good $(80.7 \%), 4$ people were not good $(19.3 \%)$ and after the intervention was good 21 people (90.7), 2 people poor (9.3). The results of the bivariate analysis showed that health education with emotional demonstration techniques had a significant effect on maternal knowledge with a value of $P=0.000$, and for attitudes also showed significant results with a value of $P=0.032$. Health education with emotional demonstration techniques needs to be introduced to the community, and regular planning needs to be made by involving all related parties so that they can work together to achieve the goals of a smart and healthy society.
\end{abstract}

Keywords: attitude, healthy snacks, knowledge

\begin{abstract}
Abstrak
Konsumsi makanan anak-anak biasanya dipengaruhi oleh bagaimana kondisi dalam rumah tangganya, ibu yang mempunyai peranan penting dalam mengajari, memilihkan dan bahkan mencontohkan anak tentang makanan dan jajanan yang dikonsumsi. Tujuan penelitian yaitu mengetahui bagaimana pengaruh pendidikan kesehatan dengan teknik emotional demonstration terhadap pengetahuan dan sikap ibu dalam memberikan jajanan yang sehat pada anak di TK Baiturrahim Jambi.Penelitian ini merupakan penelitian kuantitatif dengan desain quasi eksperimen. Populasi penelitian ini berjumlah 23 orang ibu-ibu yang anaknya bersekolah di TK Baiturrahim dan teknik sampel yang dipilih adalah total sampling. Pengaetahuan ibu sebelum dilakukan intervensi yaitu baik 16 orang $(68,7 \%)$, kurang baik 7 orang $(31,3 \%)$ dan setelah dilakukan intervensi yaitu baik 21 orang $(91,3 \%)$, kurang baik 2 orang $(8,7 \%)$. Sedangkan untuk variabel sikap didapat ibu bersikap baik 19 orang $(80,7 \%)$, kurang baik 4 orang $(19,3 \%)$ dan setelah dilakukan intervensi yaitu baik 21 orang $(90,7)$, kurang baik 2 orang $(9,3)$. Hasil analisis bivariat menunjukkan Pendidikan kesehatan dengan teknik emotional demonstration mempunyai pengaruh yang signifikan terhadap pengetahuan ibu dengan nilai $\mathrm{P}=0,000$, dan untuk sikap juga menunjukkan hasil yang signifikan dengan nilai $\mathrm{P}=0,032$. Pendidikan kesehatan dengan teknik emotional demonstration perlu untuk lebih dikenalkan pada masyarakat, serta perlu dibuat perencanaan yang reguler dengan melibatkan semua pihak terkait agar dapat bekerja bersama mencapai tujuan masyarakat cerdas dan sehat.
\end{abstract}

Kata Kunci : jajanan sehat, pengetahuan, sikap 


\section{PENDAHULUAN}

Keterlambatan dalam merespon, yang biasanya datang dari sikap mengulur-ngulur waktu dapat berakibat fatal dalam situasi krisis.Dalam masa krisis dimana situasi bergulir dengan cepat, satu elemen yang sangat penting adalah respon yang real time. Real time di sini berarti tepat waktu dan tidak tertinggal oleh roda-roda perkembangan kejadian (Djalal, ).

Gizi yang baik sangat diperlukan untuk proses tumbuh kembang anak yang normal. Kebiasaan makan yang timbul sejak usia anak-anak akan dipertahankan seumur hidup. Karena itu, seorang bayi setelah usia 6 bulan harus memperoleh makanan yang bergizi dan beraneka ragam jenisnya sehingga mendorong terbentuknya kebiasaan makan yang sehat.

Akhir-akhir ini pada masyarakat kota besar yang sibuk ada kecendrungan meningkatnya kebiasaan makan yang praktis dan dapat segera dinikmati. Makanan semacam ini dibuat oleh industryindustri makanan yang mengenali kesempatan pasar yang baru sehingga mereka mengembangkan jenis-jenis makanan baru yang praktis.Bahan makanan yang dibekukan seperti yang terdapat dipasar-pasar swalayan memudahkan kita untuk memperoleh bahan makanan apapun di sepanjang tahun.Beberapa jenis bahan makanan yang diproduksi oleh industry makanan memang ada yang diperkaya nutriennya, misalnya penambahan vitamin A ke dalam mie instan.Namun, secara umum, makanan praktis memiliki kandungan gula dan garam yang tinggi.

Makanan yang setelah dibeli, langsung dapat dimakan ( take away meals) seperti hamburger, pizza, hot dog dan lainlain kini semakin popular di kota-kota besar. Jenis makanan ini biasanya berbeda dengan makanan yang dimasak dirumah dan kerapkali dianggap sebagai junkfood.Untuk memperoleh makanan yang gizinya baik dan seimbang, kita harus menghindari makanan berlemak atau makanan yang digoreng dengan banyak minyak sementara sayur-sayuran termasuk lalapan diikutsertakan di dalam hidangan.

Di kota-kota besar memang sudah sukar ditemukan tanda-tanda nyata yang menunjukan keadaan defisiensi protein akibat salah diet, namun kita tidak mengetahui sampai sejauh mana defisiensi ringan dapat terjadi dan bertanggungjawab atas gangguan pertumbuhan serta kesehatan yang buruk. Masukan protein yang paspasan harus dihindari, terutama pada masamasa dimana terdapat peningkatan kebutuhan akan protein, seperti pertumbuhan, kehamilan, laktasi dan selama masa kesembuhan dari cedera, karena kekurangan protein dapat meningkatkan kerentanan terhadap infeksi.

Tujuan dasar pencernaan dan absorbsi adalah untuk mengantarkan zat gizi esensial ke sel untuk kelangsungan hidup. Agar dapat memecah makanan menjadi zat gizi esensial ini, tubuh mengolah makanan melalui berbagai proses kimia dan mekanik dalam traktus gastrointestinal atau saluran cerna.(3)

Berdasarkan hasil Riset Kesehatan Dasar (Riskesdas) tahun 2013 didapat hasil prevalensi gizi di Indonesia terdiri dari $5,7 \%$ gizi buruk dan $13,9 \%$ gizi kurang. Angka prevalensi gizi buruk meningkat dari 4,9\% pada tahun 2010 dan 5,7\% tahun 2013. Sedangkan prevalensi gizi kurang naik sebesar 0,9\% dari 2010 dan 2013 sebsear $13,9 \%$. Untuk mencapai sasaran MDGS tahun 2016 yaitu 15,5\% maka prevalensi gizi buruk-kurang secara nasional harus diturunkan sebesar $4.1 \%$ dalam periode 2013 sampai 2016 (Kemenkes RI, 2013).

Masalah gizi yang harus dihadapi Indonesia pada saat ini adalah masalah gizi kurang dan masalah gizi lebih.Masalah gizi kurang disebabkan oleh kemiskinan, kurangnya persediaan pangan, sanitasi lingkungan yang kurang baik, kurangnya pengetahuan masyarakat tentang gizi dan kesehatan, sedang masalah gizi lebih 
disebabkan oleh kemajuan ekonomi pada masyarakat disertai dengan kurangnya pengetahuan gizi dan kesehatan (Waryana, 2010).

Faktor utama yang paling mempengaruhi tumbuh kembang balita secara normal adalah asupan makanan yang kuantitas dan kualitasnya baik. Hal tersebut sangat bermanfaat bagi proses pertumbuhan dan perkembangan serta menjaga kesehatan upaya pencegahan beberapa penyakit atau masalah kesehatan (Badriah, 2011).

Konsumsi makanan anak-anak biasanya dipengaruhi oleh bagaimana kondisi dalam rumah tangganya, ibu yang mempunyai peranan penting dalam mengajari, memilihkan dan bahkan mencontohkan anak tentang makanan dan jajanan yang dikonsumsi dalam keluarga perlu memiliki pengetahuan yang baik tentang makanan, jenis dan kandungan gizi serta zat lain yang terdapat dalam makanan. Melihat kondisi masyarakat saat ini yaitu bagaimana gaya hidup, pola memilih makanan dan konsumsi jajanan yang dijual dipasaran terutama yang dijual oleh pedagang penjaja makanan di sekolah taman kanak-kanak maka peneliti tertarik untuk melakukan penelitian tentang “ Pengetahuan dan Sikap Ibu dalam Pemilihan Jajanan sehat pada anak di TK Baiturrahim".

Tujuan penelitian ini yaitu untuk mengetahui bagaimana pengetahuan dan sikap ibu dalam memberikan jajanan yang sehat pada anak di Taman Kanak-Kanak Baiturrahim Jambi.

\section{METODE PENELITIAN}

Penelitian ini merupakan penelitian kuantitatif, menggunakan desain quasi eksperimen untuk mengetahui pengaruh pendidikan kesehatan dengan teknik emotional demonstrastion terhadap pengetahuan dan sikap ibu tentang pemberian makanan jajanan sehat pada anak di TK Baiturrahim Jambi. Populasi penelitian adalah seluruh orang tua murid TK Baiturrahim yang berjumlah 23 orang. Teknik sampel yang dipakai adalah total sampling. Penelitian dilakukan dengan cara memberikan pendidikan kesehatan tentang pemberian jajanan sehat dengan teknik emotional demostration yang ditujukan untuk mempengaruhi pengetahuan dan sikap ibu. Alat ukur yang digunakan adalah kuesioner yang harus diisi oleh para responden sebelum dilakukan pendidikan kesehatan dan setelah dilakukan pendidikan kesehatan. Analisa data dilakukan secara univariat dan bivariat melalui uji statistiknya yaitu T-Test.

\section{HASIL PEMBAHASAN \\ Analisis Univariat}

Pada uji statistik univariat dilakukan 2 (dua) kali yaitu sebelum melakukan intervensi (pre test) dan sesudah dilakukan intervensi (post test).

\section{Pengetahuan Ibu Dalam Memberikan Jajanan Yang Sehat Pada Anak}

Pengetahuan ibu sebelum dan sesudah dilakukan pendidikan kesehatan dengan teknik emotional demonstration pada ibu di tk baiturrahim jambi dapat dilihat pada Tabel 1 di bawah ini 
Tabel 1. Distribusi Jawaban Pertanyaan Pengetahuan Ibu Sebelum Dan Sesudah Dilakukan Pendidikan Kesehatan Dengan Teknik Emotional Demonstration Pada Ibu Di TK Baiturrahim Jambi

\begin{tabular}{|c|c|c|c|c|c|c|c|c|c|}
\hline \multirow{3}{*}{ No } & \multirow{3}{*}{ Item Pertanyaan } & \multicolumn{4}{|c|}{ Pre Test } & \multicolumn{4}{|c|}{ Post Test } \\
\hline & & \multicolumn{2}{|c|}{$\begin{array}{l}\text { Jawaban } \\
\text { Benar }\end{array}$} & \multicolumn{2}{|c|}{$\begin{array}{l}\text { Jawaban } \\
\text { Salah }\end{array}$} & \multicolumn{2}{|c|}{$\begin{array}{l}\text { Jawaban } \\
\text { Benar }\end{array}$} & \multicolumn{2}{|c|}{$\begin{array}{c}\text { Jawaban } \\
\text { Salah }\end{array}$} \\
\hline & & $\mathbf{F}$ & $\%$ & $\mathbf{F}$ & $\%$ & $\mathbf{F}$ & $\%$ & $\mathbf{F}$ & $\%$ \\
\hline 1 & $\begin{array}{l}\text { Cemilan anak saya } \\
\text { biasanya }\end{array}$ & 11 & 47,8 & 11 & 47,8 & 20 & 87 & 3 & 13 \\
\hline 2 & $\begin{array}{l}\text { Cemilan yang } \\
\text { sehat sehat } \\
\text { biasanya adalah }\end{array}$ & 19 & 82,6 & 19 & 82,6 & 23 & 100 & 0 & 0 \\
\hline 3 & $\begin{array}{l}\text { Setiap pergi } \\
\text { kesekolah anak } \\
\text { saya biasanya }\end{array}$ & 10 & 43,5 & 13 & 56,5 & 22 & 95,7 & 1 & 4,3 \\
\hline 4 & $\begin{array}{l}\text { Jajanan yang sehat } \\
\text { sebaiknya..kecuali }\end{array}$ & 17 & 73,9 & 6 & 26,1 & 17 & 73,9 & 6 & 26,1 \\
\hline 5 & $\begin{array}{l}\text { Makin sering anak } \\
\text { mengkonsumsi } \\
\text { cemilan } \\
\text { sembarangan maka }\end{array}$ & 22 & 95,7 & 1 & 4,3 & 23 & 100 & 0 & 0 \\
\hline
\end{tabular}

Adapun untuk melihat secara keseluruhan distribusi pengetahuan responden dalam memberikan jajanan pada anak di TK Baiturrahim Jambi dapat di lihat pada tabel 2 di bawah ini .

Tabel 2 Distribusi Pengetahuan Ibu Dalam Memilih Jajanan Anak Di TK Baiturrahim Jambi

\begin{tabular}{lllcccc}
\hline No & Pengetahuan & \multicolumn{3}{c}{ Pre Test } & \multicolumn{2}{c}{ Post Test } \\
\cline { 3 - 6 } & & \multicolumn{3}{c}{ F } & \% & \multicolumn{2}{c}{ F } & \% \\
1 & Baik & 16 & 68,7 & 21 & 91,3 \\
2 & Kurang Baik & 7 & 31,3 & 2 & 8,68 \\
\hline
\end{tabular}

Hasil penelitian pada variabel pengetahuan di dapat bahwa nilai mean pada saat pre test adalah 3, 4348 dan mean post test 4, 5652. Pengetahuan ibu dalam kondisi pre intervensi dapat diketahui dengan melihat distribusi jawaban yang dipilih dengan benar oleh para responden dari 5 pertanyaan yang diajukan bahwa setiap item pertanyaan lebih banyak dijawab dengan benar lebih dari sebagian responden kecuali untuk pertanyaan no 3 yaitu pertanyaan yang menanyakan tentang kebiasaan ibu dalam membawakan bekal anaknya kesekolah. Pertanyaan yang diisi sebelum ada intervensi dari peneliti ini merupakan pengetahuan murni dari para responden sebelum diberikan pendidikan kesehatan dengan metode emotional demonstration. Pertanyaan yang paling banyak dijawab benar adalah pertanyaan no 5 dengan persentase responden yang menjawab benar yaitu 95, $7 \%$ hampir 
mendekati angka $100 \%$ Hal ini mengindikasikan bahwa hampir seluruh responden sudah memiliki pengetahuan bahwa makin makin sering anak mengkonsumsi cemilan sembarangan maka akan semakin banyak zat berbahaya yang masuk dalam tubuh anaknya. Pengetahuan yang masih dijawab salah oleh lebih dari sebagian responden yaitu tentang kebiasaan membawakan anak mereka bekal ke sekolah. Banyak kemungkinan yang bisa diasumsikan tentang mengapa para ibu tidak memiliki pengetahuan yang baik tentang pentingnya membawakan bekal anaknya kesekolah, hal ini bisa juga dikarenakan ibu menganggap jajanan yang dijual disekolah aman dan sehat untuk dikonsumsi oleh anak atau dapat juga mereka berasumsi bahwa jika anak jajan disekolah hanyalah dalam jumlah yang sedikit atau hanya berupa makanan tambahan saja sedangkan makanan pokok atau yang utama tetap dapat diberikan dirumah. Namun masih banyak kemungkinan lainnya yang bisa saja menjadi alasan para responden atau ibu.
Sedangkan

untuk variabel pengetahuan setelah diberikan intervensi dapat di lihat yaitu bahwa semua pertanyaan yang ada lebih dari sebagian besar dijawab dengan benar oleh para responden dengan jumlah persentase tertinggi ada pada pertanyaan no 2 dan 5 yaitu 100 persen responden menjawab benar dan untuk nilai terendah yaitu ada pada pertanyaan no 4 yaitu 73,9 persen responden menjawab rendah. Hal ini menunjukkan adanya perubahan pengetahuan responden pada kondisi sebelum dan sesudah dilakukannya intervensi berupa pendidikan kesehatan dengan metode emotional demonstration.

\section{Sikap Ibu Dalam Memberikan Jajanan Pada Anak}

Sikap ibu sebelum dan sesudah dilakukan pendidikan kesehatan dengan teknik emotional demonstration pada di TK Baiturrahim Jambi dapat dilihat pada Tabel.3 di bawah ini

Tabel 3 Distribusi Pernyataan Sikap Ibu Dalam Memberikan Jajanan Sehat Pada Anak Sebelum Dan Sesudah Dilakukan Pendidikan Kesehatan Dengan Teknik Emotional Demonstration Di Tk Baiturrahim Jambi

\begin{tabular}{|c|c|c|c|c|c|c|c|c|c|}
\hline \multirow{3}{*}{$\begin{array}{l}\mathbf{N} \\
\mathbf{O}\end{array}$} & \multirow{3}{*}{$\begin{array}{c}\text { ITEM } \\
\text { PERNYATAAN }\end{array}$} & \multicolumn{4}{|c|}{ Pre Test } & \multicolumn{4}{|c|}{ Post Test } \\
\hline & & \multicolumn{2}{|c|}{ Setuju } & \multicolumn{2}{|c|}{ Tdk Setuju } & \multicolumn{2}{|c|}{ Setuju } & \multicolumn{2}{|c|}{ Tdk Setuju } \\
\hline & & f & $\%$ & $\mathbf{F}$ & $\%$ & f & $\%$ & $\mathbf{F}$ & $\%$ \\
\hline 1 & $\begin{array}{l}\text { Saya biasanya } \\
\text { membelikan jajanan } \\
\text { yang diminta anak } \\
\text { saya disekolah }\end{array}$ & 8 & 34,8 & 15 & 65,2 & 2 & 8,7 & 21 & 91,3 \\
\hline 2 & $\begin{array}{l}\text { Saya biasanya } \\
\text { membawakan bekal } \\
\text { anak saya jika ke } \\
\text { sekolah }\end{array}$ & 21 & 91,3 & 2 & 8,7 & 23 & 100 & - & - \\
\hline 3 & $\begin{array}{l}\text { Saya biasanya } \\
\text { memasak sendiri } \\
\text { makanan bekal anak } \\
\text { saya ke sekolah }\end{array}$ & 21 & 91,3 & 2 & 8,7 & 23 & 100 & - & - \\
\hline 4 & $\begin{array}{l}\text { Cemilan yang sehat } \\
\text { menurut saya adalah } \\
\text { makanan yang saya }\end{array}$ & 23 & 100 & 0 & 0 & 23 & 100 & - & - \\
\hline
\end{tabular}




\begin{tabular}{|c|c|c|c|c|c|c|c|c|c|}
\hline & $\begin{array}{l}\text { masak sendiri atau bisa } \\
\text { juga sayur dan buah } \\
\text { segar }\end{array}$ & & & & & & & & \\
\hline 5 & $\begin{array}{l}\text { Saya sering tidak tega } \\
\text { jika anak saya minta } \\
\text { jajajnan }\end{array}$ & 13 & 56,5 & 10 & 43,5 & 7 & 30,7 & 16 & 69,6 \\
\hline 6 & $\begin{array}{l}\text { Saya akan biarkan } \\
\text { anak saya menangis } \\
\text { jika meminta jajanan } \\
\text { yang menurut saya } \\
\text { tidak sehat }\end{array}$ & 19 & 82,6 & 4 & 17,4 & 20 & 87 & 3 & 13 \\
\hline 7 & $\begin{array}{l}\text { Jika anak saya } \\
\text { memakan makanan } \\
\text { jajanan yang tidak } \\
\text { sehat, saya biasanya } \\
\text { beri air putih yang } \\
\text { banyak agar dapat } \\
\text { tetap sehat }\end{array}$ & 21 & 9,3 & 2 & 8,7 & 20 & 87 & 3 & 13 \\
\hline
\end{tabular}

Adapun untuk melihat secara keseluruhan distribusi sikap responden dalam memberikan jajanan pada anak di
TK Baiturrahim Jambi dapat di lihat pada tabel 4.4 di bawah ini .

Tabel 4 Distribusi Sikap Ibu Dalam Memberikan Jajanan Pada Anak Di TK Baiturrahim Jambi

\begin{tabular}{|c|c|c|c|c|c|}
\hline \multirow[t]{2}{*}{ No } & \multirow[t]{2}{*}{ Sikap } & \multicolumn{2}{|c|}{ Pre Test } & \multicolumn{2}{|c|}{ Post Test } \\
\hline & & $\mathbf{F}$ & $\%$ & $\mathbf{f}$ & $\%$ \\
\hline 1 & Baik & 19 & 80,7 & 4 & 19,3 \\
\hline 2 & Kurang Baik & 21 & 90,7 & 2 & 9,3 \\
\hline
\end{tabular}

Hasil penelitian untuk melihat sikap responden dapat di lihat bahwa jumlah responden/ibu yang memiliki sikap dalam memberikan jajanan yang baik lebih besar dari jumlah responden/ibu yang memiliki sikap kuarng baik yaitu Sikap responden terhadap pemberian jajanan sehat pada anak sebelum dilakukan intervensi dapat dilihat pada tabel 4.3 diatas yaitu ada 7 pertanyaan yang jika dipilih oleh responden maka akan terlihat gambaran bagaimana sikap positif dan negatif yang dimiliki responden dengan pernyataan setuju atau tidak setuju yang dipilihnya. Pada pernyataan no 1 dan 5 jika responden menjawab setuju maka hal tersebut akan menunjukkan sikap negatif responden terhadap pemilihan jajanan yang diberikan pada anak mereka sedangkan untuk pertanyaan no 2, 3, 4, 6 dan 7 jika responden memberi pernyataan setuju maka berarti mereka memiliki sikap positif terhadap prilaku dalam pemilihan jajanan untuk anak. Jadi dapat dilihat untuk pertanyaan no 1 dapat dilihat bahwa sebagian besar responden memiliki sikap yang positif dalam memilih jajanan untuk anak, hal ini berbeda dengan pernyataan no 5 dimana hanya sebagian kecil responden yang memilki sikap positif dalam memilih jajanan untuk anak. Sedangkan untuk pernyataan no 2, 3, 4, 6 dan 7 dapat dilihat bahwa lebih dari dari sebagian besar responden sudah memiliki sikap positif dalam memilih jajanan untuk anak terutama untuk pernyataan no 4 seluruh responden yaitu 100 persen memiliki sikap positif untuk memilih jajanan yang sehat untuk anak. 
Pada hasil distribusi terhadap pernyataan responden terhadap sikap pemilihan jajanan untuk anak setelah dilakukan intervensi dengan metode emotional demonstration dapat dilihat pada tabel 4.4 di atas yaitu lebih dari sebagian besar responden telah memiliki sikap yang positif terhadap pemilihan jajanan pada anak. Nilai yang ditunjukkan pada setiap item pernyataan mengalami peningkatan bahkan ada 3 dari 7 pernyataan memilki angka positif 100 persen yaitu pada pernyataan no 2, 3 dan 4 .

\section{Analisa Bivariat}

\section{a. Pengetahuan}

Hubungan pendidikan kesehatan dengan metode emotional demonstration terhadap tingkat pengethuan ibu sebagai responden dalam penelitian dapat dilihat pada tabel 5 di bawah ini

Tabel 5 Pengaruh Pendidikan Kesehatan Dengan Metode Emotional Demonstration Terhadap Pengetahuan Ibu Dalam Memberikan Jajanan Pada Anak Di TK Baiturrahim Jambi

\begin{tabular}{lccccc}
\hline \multicolumn{1}{c}{ Variabel } & Mean & $\begin{array}{c}\text { Standar } \\
\text { Deviation }\end{array}$ & $\begin{array}{c}\text { Standar } \\
\text { Error }\end{array}$ & $\begin{array}{c}\text { P- } \\
\text { Value }\end{array}$ & N \\
\hline $\begin{array}{l}\text { Pengetahuan sebelum } \\
\text { pemberian pendidikan }\end{array}$ & 3,4348 & & & & \\
$\begin{array}{l}\text { kesehatan dengan metode } \\
\text { emotional demonstration (Pre }\end{array}$ & & 1,37597 & 0,28691 & & \\
$\begin{array}{l}\text { Test) } \\
\begin{array}{l}\text { Pengetahuan } \\
\text { sesudahpemberian pendidikan } \\
\text { kesehatan dengan metode } \\
\text { emotional demonstration(Post }\end{array}\end{array}$ & 4,5652 & & & 0,000 & 23 \\
Test) & & 0,66237 & 0,13811 & & \\
\hline
\end{tabular}

Pada tabel 5 dapat dilihat bahwa pendidikan kesehatan yang diberikan dengan metode emotional demonstration memberikan pengaruh yang signifikan dalam meningkatkan pengetahuan ibu/responden dalam memberikan jajanan pada anak dengan nilai $\mathrm{p}=0,000$. Pengetahuan yang baik terutama tentang pemilihan makanan terhadap anak tentunya merupakan hal penting karena makanan yang dikonsumsi oleh anak akan terserap kedalam tubuhnya dan berpengaruh langsung pada anak untuk pertumbuhan dan perkembangannya. Jika orang tua lalai untuk memperhatikan makanan terbaik yang dikonsumsi oleh anaknya maka dampak yang akan diperoleh anak bukan hanya berupa penyakit yang mengganggu kesehatan saat ini namun juga akan berdampak bagi anak dimasa yang akan datang bahkan bisa mengakibatkan gagal tumbuh. Dampak lain yang bisa terjadi jika anak makan atau jajan makanan yang ternyata mengandung zat makanan yang tidak sehat maka dampaknya akan bisa menimbulkan penyakit yang dapat berdampak buruk pada organ tubuh orang yang mengkonsumsinya.

Jajanan yang biasanya disukai oleh anak-anak adalah jajanan yang memiliki warna menarik, bentuk yang unik juga jajanan yang dianggap mereka merupakan jajanan yang trending atau viral. Anak terkadang juga menyukai makanan yang biasa di konsumsi oleh teman-temannya atau cenderung ikut-ikutan.

Makanan yang setelah dibeli, langsung dapat dimakan ( take away meals) 
seperti hamburger, pizza, hot dog dan lainlain kini semakin popular di kota-kota besar. Jenis makanan ini biasanya berbeda dengan makanan yang dimasak dirumah dan kerapkali dianggap sebagai junkfood.Untuk memperoleh makanan yang gizinya baik dan seimbang, kita harus menghindari makanan berlemak atau makanan yang digoreng dengan banyak minyak sementara sayur-sayuran termasuk lalapan diikutsertakan di dalam hidangan.

Di kota-kota besar memang sudah sukar ditemukan tanda-tanda nyata yang menunjukan keadaan defisiensi protein akibat salah diet, namun kita tidak mengetahui sampai sejauh mana defisiensi ringan dapat terjadi dan bertanggungjawab atas gangguan pertumbuhan serta kesehatan yang buruk. Masukan protein yang paspasan harus dihindari, terutama pada masamasa dimana terdapat peningkatan kebutuhan akan protein, seperti pertumbuhan, kehamilan, laktasi dan selama masa kesembuhan dari cedera, karena kekurangan protein dapat meningkatkan kerentanan terhadap infeksi.

Pengetahuan seorang ibu sebagai pengasuh utama dari anak akan sangat mempengaruhi dan menjadi pedoman bagi sikap serta prilaku seorang anak dalam memilih dan mengkonsumsi makanan bagi dirinya. Ibu akan dapat memunculkan kebiasaan yang baik bagi anak. Memberikan pengertian dan mengarahkan saaat anak merengek meminta jajanan, memilih cara yang tepat serta membantu anak menambah pengetahuan adalah tugas ibu sebagai pengasuhnya. Pertumbuhan dan perkembangan anak sangat dipengaruhi oleh pola asuh yang diberikan ibu. Faktor utama yang paling mempengaruhi tumbuh kembang balita secara adalah asupan makanan yang kuantitas dan kualitasnya baik. Hal tersebut sangat bermanfaat bagi proses pertumbuhan dan perkembangan serta menjaga kesehatan upaya pencegahan beberapa penyakit atau masalah kesehatan (Badriah, 2011).

Mengingat pentingnya pengetahuan seorang ibu maka harus ada pihak yang terus mensupport ibu untuk terus menambah pengetahuannya.Cara yang paling efektif untuk menambah pengetahuan ibu salah satunya bisa dengan memberikan pendidikan pada ibu sehingga harus terus dipilih teknik untuk meningkatkan pengetahuan ibu yang paling efektif.Faktor-faktor yang mempengaruhi pengetahuan adalah (Wawan, 2010): Faktor internal berupa ; Pendidikan, Pekerjaan, Umur, sedangkan Faktor Eksternal berupa ; Faktor lingkungan, Sosial budaya. Pada penelitian ini upaya yang dilakukan yaitu meningkatkan pengetahuan ibu dengan memberikan pendidkan dengan teknik emotional demonstration. Teknik ini adalah teknik yang dipilih karena dapat meningkatkan pengetahuan seseorang yang mengikutinya dengan cara menyentuh emotional orang tersebut dengan cara mendemonstrasikan langsung materi pendidikan yang dilakukan oleh pendidik dan peserta didik yang dalam hal ini adalah ibu-ibu sebagai orang tua dari anak di TK Baiturrahim

Jika anak mengkonsumsi jajanan dengan baik maka kesehatannyapun akan menjadi baik pula. Dia dapat terus tumbuh dan berkembang dengan baik hingga mencapai batas maksimal. Agar semua hal tersebut dapat terwujud maka pentingsekali untuk terus meningkatkan pengetahuan orang tua terutama ibu.

\section{Sikap}

Pada uji statistik pengaruh pendidikan kesehatan dengan teknik emotional demonatration terhadap sikap ibu dalam memberikan makan pada anak dapat dilihat pada tabel 6 di bawah ini 
Tabel 6 Pengaruh Pendidikan Kesehatan Dengan Metode Emotional Demonstration Terhadap Sikap Ibu Dalam Memberikan Jajanan Pada Anak Di TK Baiturrahim Jambi

\begin{tabular}{|c|c|c|c|c|c|}
\hline Variabel & Mean & $\begin{array}{c}\text { Standar } \\
\text { Deviation }\end{array}$ & $\begin{array}{c}\text { Standar } \\
\text { Error }\end{array}$ & P-Value & $\mathbf{N}$ \\
\hline $\begin{array}{l}\text { sikap sebelum pemberian } \\
\text { pendidikan kesehatan dengan } \\
\text { metode emotional demonstration } \\
\text { (Pre Test) }\end{array}$ & 5,6522 & 1,11227 & 0,23193 & 0.032 & 23 \\
\hline $\begin{array}{l}\text { Sikap sesudah sebelum } \\
\text { pemberian pendidikan kesehatan } \\
\text { dengan metode emotional } \\
\text { demonstration (Post Test) }\end{array}$ & 6,3478 & 0,71406 & 0,14889 & & \\
\hline
\end{tabular}

Hasil data statistik untuk pengaruh pendidikan terhadap sikap ibu dalam memilih jajanan pada anak dapat dilihat pada tabel 4. 6 di atas. Adapun hasilnya menunjukkan bahwa pendidkan memberikan pengaruh yang signifikan terhadap sikap ibu dalam memberikan jajanan pada anak dengan nilai $\mathrm{p}=0,032$.

Sikap yang baik tentunya diawali dengan pengetahuan yang baik. Jika seorang ibu memiliki pengetahuan yang baik tentu sikapnya juga akan baik dalam mengambil keputusan akan prilaku yang dilakukannya. Sikap akan menumbuhkan keyakinan dalam berprilaku. Sikap seorang ibu akan dapat menjadi dasar dalam pemilihan prilaku baginya untuk bertindak dalam menentukan atau memberikan makanan jajanan yang baik pada anaknya. Makanan yang baik tent

Seorang ibu sebagai pengasuh utama dari anak sebaiknya mempunyai sikap yang baik. Hal ini juga berlaku dalam pemilihan makanan yang baik untuk anaknya. Memilihkan makanan yang tepat untuk dikonsumsi oleh anak akan membantu anak dapat mengkonsumsi makanan yang sehat dan bermanfaat untuk kelangsungan hidupnya dalam proses tumbuh kembang agar dapat menjadi semaksimal mungkin yang dapat dicapai.

Gizi yang baik sangat diperlukan untuk proses tumbuh kembang anak yang normal. Kebiasaan makan yang timbul sejak usia anak-anak akan dipertahankan seumur hidup. Karena itu, seorang bayi setelah usia 6 bulan harus memperoleh makanan yang bergizi dan beraneka ragam jenisnya sehingga mendorong terbentuknya kebiasaan makan yang sehat.

Akhir-akhir ini pada masyarakat kota besar yang sibuk ada kecendrungan meningkatnya kebiasaan makan yang praktis dan dapat segera dinikmati. Makanan semacam ini dibuat oleh industryindustri makanan yang mengenali kesempatan pasar yang baru sehingga mereka mengembangkan jenis-jenis makanan baru yang praktis.Bahan makanan yang dibekukan seperti yang terdapat dipasar-pasar swalayan memudahkan kita untuk memperoleh bahan makanan apapun di sepanjang tahun.Beberapa jenis bahan makanan yang diproduksi oleh industry makanan memang ada yang diperkaya nutriennya, misalnya penambahan vitamin A ke dalam mie instan.Namun, secara umum, makanan praktis memiliki kandungan gula dan garam yang tinggi.

Faktor utama yang paling mempengaruhi tumbuh kembang balita secara normal adalah asupan makanan yang kuantitas dan kualitasnya baik. Hal tersebut sangat bermanfaat bagi proses pertumbuhan dan perkembangan serta menjaga kesehatan 
upaya pencegahan beberapa penyakit atau masalah kesehatan (Badriah, 2011).

Setiap zat gizi memiliki peranya masing-masing dalam fungsi metabolism, tetapi tidak ada yang bekerja sendiri. Terdapat hubungan metabolic yang erat diantara zat-zat gizi dasar, begitu juga dengan produk-produk metaboliknya. Zat gizi nonesensial adalah nutrisi yang tidak harus ada dalam makanan karena dapat dibentuk di dalam tubuh.

Sistem Promosi kesehatan harus mencakup semua kebutuhan, termasuk kebutuhan fisik, emosi, mental, dan social. Seseorang dikatakan sehat atau baik, hanya jika seluruh krbutuhan tersebut dapat terpenuhi.Lebih lanjut, sejahtera berarti keadaan yang seimbang antara aktivitas seseorang dengan tujuannya.Mempertahankan keseimbangan ini membuat seseorang dapat menjaga vitalitas dan kemampuannya untuk berfungsi dengan produktif di masyarakat. Makanan bergizi menjadi dasar promosi kesehatan dan pencegahan penyakit,dan hal ini membuatnya menjadi bagian penting dalam perawatan setiap orang.

Banyak orang yang merasa prihatin terhadap keberadaan bahan tambahan kimia dalam makanan mereka dan mereka khawatir tentang dampak buruk setelah mengkonsumsinya. Apa yang biasanya dimaksud dengan bahan kimia berkaitan dengan makanan dan zat-zat yang biasanya bukan merupakan bagian dari makanan dalam keadaan yang alami dan tradisional. Keberadaan mereka dapat disebabkan karena kontaminasi yang tidak disengaja, atau mereka dapat ditambahkan secara bebas untuk meningkatkan pemrosesan atau mempertahankan kualitas atau untuk menjadi pelengkap dari nutrisi yang telah ada.

Jika seorang anak terbiasa mengkonsumsi jajanan dan ternyata jajajnan itu tidak sehat maka dapat dilihat bahaya yang akan terjadi dan tentunya selain menyebabkan gagal tumbuh, anak tersebut juga akan mendapat beberapa penyakit berbahaya sebagai dampak dari mengkonsumsi jajanan tersebut. Zat aditif merupakan zat alami atau buatan yang ditambahkan pada makanan dengan beberapa tujuan. Definisi legal mengenai zat aditif adalah setiap zat yang tidak biasanya dikonsumsi sebagai makanan dengan sendirinya dan tidak biasanya digunakan sebagai bahan khas makanan, baik itu memiliki nilai nutrisi atau tidak, baik penambahan yang disengaja terhadap makanan untuk tujuan teknologi di perusahaan, pemrosesan, persiapan, perawatan, pengemasan, transportasi dan penyimpanan hasil produksi makanan tersebut, atau mungkin cukup menghasilkan seperti yang diharapkan, memberikan dampak tertentu atau tidak, yang secara langsung atau tidak langsung menjadi komponen dari makanan tersebut.

Mengingat pentingnya untuk menumbuhkan sikap yang baik pada ibu dalam memberikan jajanan pada anak maka perlu dipikirkan oleh tim promosi kesehatan untuk secara reguler memberikan pendidikan kesehatan pada masyarakat terutama pada ibu yang mempunyai bayi dan balita. Kegiatan promosi kesehatan yang dilakukan haruslah dilakukan ke segala lini yaitu pada instansi formal ataupun di kelompok masyarakat yang tidak formal.

\section{SIMPULAN}

Pendidikan kesehatan dengan teknik emotional demonstration mempunyai pengaruh yang signifikan terhadap pengetahuan ibu dalam memberikan jajanan pada anak di TK Baiturrahim jambi dengan nilai $\mathrm{p}(\mathrm{p}$ value $)=0,000$. Serta pendidikan kesehatan dengan teknik emotional demonstration juga mempunyai pengaruh yang signifikan terhadap sikap ibu dalam memberikan jajanan pada anak di TK Baiturrahim jambi dengan nilai $\mathrm{p}$ ( $\mathrm{p}$ value) $=0,032$. 
Pendidikan kesehatan dengan teknik emotional demonstration perlu untuk lebih dikenalkan pada masyarakat mengingat pengaruh yang diberikan sangat signifikan bagi peningkatan pengetahuan dan sikap ibu ke arah yang lebih baik.

\section{SARAN}

Petugas kesehatan harus lebih sering dan membuat perencanaan secara reguler untuk selalu memberikan pendidikan kesehatan kepada masyarakat untuk dapat mencerdaskan bangsa. Pendidkan kesehatan bukan hanya menjadi tugas dari dinas kesehatan dan jajarannya tapi juga menjadi tanggung jawab semua tenaga kesehatan di semua lini termasuk tenaga pendidik kesehatan yang berada di kampus. Memberikan jajanan yang sehat pada anak sangatlah penting karena akan membantu tumbuh kembang anak sebagai patokan kesehatannya di masa yang akan datang.

\section{DAFTAR PUSTAKA}

Abdelbasset, W.K.M., Elnegamy, T.E.H. (2015). Effect of chest physical therapy on pediatrics hospitalized with pneumonia. International Journal of Health and Rehabilitation Science, 4(4), 219226.

Ball, J.W., Bindler, R.C., \& Cowen, K.J. (2010).Child health nursing, partnering withchildren \& families. (2nd ed). New Jersey:Pearson Education inc.
Bowden, V.R., \& Greenberg, C.S. (2010).Children and their families: the continuum of care. ( $2^{\text {nd }}$ edition). Philadelphia: Lippincott Williams \& Wilkins.

Hockenberry, M.J., \& Wilson, D. (2009).Wong's essentials of pediatric nursing. ( $8^{\text {th }}$ edition). St. Louis Missouri: Elsevier Mosby.

Stricland, S.L., Rubin, B.K., Drescher, G.S., Haas, C.F., OMalley, C.A., Volsko, T.A... \& Hess, D.R. (2013). AARC Clinical practice guideline :effectiveness

Mann, Jim \& Truswell,Stewart A (2014); Buku Ajar Ilmu Gizi, Ed 4, Jakarta, EGC

Williams, Lippincott \& Wilkins (2013); Ilmu Gizi Menjadi sangat Mudah Ed.2, Jakarta, EGC

Lean, Michael E.J. (2013) ; Ilmu Pangan, Gizi \& Kesehatan, Yogyakarta, Pustaka Pelajar

Herbold, Nancie \& Edelstein, Sari (2012) ; Buku Saku Nutrisi, Jakarta, EGC

Beck, Mary E (2011); Ilmu Gizi dan Diet, Yogyakarta, Yayasan Essentia Medica

Arisman (2010), Gizi dalam Daur Kehidupan ; buku ajar ilmu gizi, ed 2, Jakarta, EGC

Budiyanto, M. Agus Krisno 92009), DasarDasar Ilmu Gizi, Malang, UMM Press Gibney, Michael, J (2009), Gizi Kesehatan Masyarakat, Jakarta, EGC 